Article

\title{
Coupled Preparation of Ferronickel and Cementitious Material from Laterite Nickel Ores
}

\author{
Ruimeng Shi ${ }^{1, *}$, Xiaoming $\mathrm{Li}^{1}{ }^{1}$, Yaru Cui ${ }^{1}$, Junxue Zhao ${ }^{1}$, Chong Zou ${ }^{1}$ and Guibao Qiu ${ }^{2, *}$ \\ 1 School of Metallurgical Engineering, Xi'an University of Architecture and Technology, Xi'an 710055, China; \\ xmli@xauat.edu.cn (X.L.); yaroo@126.com (Y.C.); Zhaojunxue1962@126.com (J.Z.); \\ zouchong985@163.com (C.Z.) \\ 2 College of Materials Science and Engineering, Chongqing University, Chongqing 400044, China \\ * Correspondence: shiruimeng@163.com (R.S.); qiuguibao@cqu.edu.cn (G.Q.)
}

Received: 24 September 2020; Accepted: 30 October 2020; Published: 5 November 2020

check for updates

\begin{abstract}
Nickel slags can be produced through ferronickel preparation by the pyrometallurgical processing of laterite nickel ores; however, such techniques are underutilized at present, and serious environmental problems arise from the stockpiling of such nickel ores. In this study, a modification to the process of ferronickel preparation by the direct reduction of carbon bases in laterite nickel ores is proposed. The gangue from the ore is used as a raw material to prepare a cementitious material, with the main components of tricalcium silicate and tricalcium aluminate. By using FactSage software, thermodynamic calculations are performed to analyze the reduction of nickel and iron and the effect of reduction on the formation of tricalcium silicate and tricalcium aluminate. The feasibility of a coupled process to prepare ferronickel and cementitious materials by the direct reduction of laterite nickel ore and gangue calcination, respectively, is discussed under varying thermodynamic conditions. Different warming strategies are applied to experimentally verify the coupled reactions. The coupled preparation of ferronickel and cementitious materials with calcium silicate and calcium aluminate as the main phases in the same experimental process is realized.
\end{abstract}

Keywords: laterite nickel ore; ferronickel; $\mathrm{C}_{3} \mathrm{~S}$ (tricalcium silicate); $\mathrm{C}_{3} \mathrm{~A}$ (tricalcium aluminate); cementitious material; process coupling

\section{Introduction}

Nickel (Ni) is a transition element that exhibits a mixture of ferrous and nonferrous metal properties, and is used in many industries, for example for making stainless steel, superalloy, non-ferrous alloy, superalloy, coin, and batteries [1-5]. World nickel reserves are abundant [6]. Identified land-based resources averaging $1 \%$ nickel or greater contain at least 130 million tons of nickel, with about $60 \%$ in laterites and $40 \%$ in sulfide deposits. In 2019, nickel resources are divided into two types of ores: sulfide and laterite, of which sulfide ore accounts for about $30 \%$ and laterite nickel ore accounts for the rest [7-9]. In China, about 70\% of nickel reserves are concentrated in Gansu Province, next to Canada's Sadbury nickel, Asia rank the first and world rank the second, followed by Xinjiang, Yunnan, Jilin, and other places [10-12]. Before 2000, because of available upgrading methods, availability of high-grade ore, and low energy consumption in the extraction process, nickel was mainly produced from sulfide $(60 \%)$, while laterite needed comprehensive treatment to extract nickel metal, resulting in a higher processing cost of laterite than nickel sulfide [13-15]. In recent years, with the rapid development of our national economy, the consumption of nickel is increasing day by day. At the same time, the total amount and grade of nickel sulfide ore resources shows a downward trend, and laterite is becoming increasingly important in the future. Therefore, pursuers begin to improve the nickel recovery technology of laterite nickel ore $[16,17]$. Laterite nickel ore has low exploration cost, 
mature technology, and broad development prospects. Therefore, nickel oxide mining is listed as a key project in China's "medium and long term scientific development and regulation of non-ferrous metal industry (2006-2020)" (draft for comments) [18,19].

The nickel content of laterite ores is very low, and special treatments are needed to improve the nickel content of these ores, such as physical separation techniques, but the complexity of laterite nickels makes it difficult to achieve any significant breakthroughs [20-25]. Thermal modification of laterite ore by carbonization, dehydration, and reduction technologies has been shown to significantly improve nickel extraction in the acid leaching stage [26-33]. Pyrometallurgy is the main process route for nickel extraction from saprolite ore, and there are two commonly used laterite nickel smelting methods $[34,35]$. One is the rotary kiln dry-electric furnace reductive smelting. The laterite nickel ore is placed in the rotary kiln for drying intervention reduction at a temperature of $650-800{ }^{\circ} \mathrm{C}$, and then placed in the reducing furnace at $1550-1600{ }^{\circ} \mathrm{C}$ for smelting and sorting to obtain coarse nickel iron. Nickel-iron alloys containing more than $25 \%$ nickel can be produced after further refining [36]. The second method is rotary kiln direct reduction. After drying, crushing, and sieving, the raw ore is mixed with lime and pulverized coal in proportion to the pellet. Drying and high temperature reduction produce spongy nickel-iron alloys and slag mixtures. After cooling, grinding, screening, and magnetic separation, the coarse nickel-iron particles were obtained. However, there are some problems in laterite nickel mining technology. In the process of rotary kiln drying-furnace reduction smelting, the melting temperature is high, the power consumption is large, the overall energy consumption is large, the slag production is large, the direct use failure is serious. Due to the direct reduction of rotary kiln, tailings yield is large and slag cannot be directly used, which increases the cost of subsequent treatment of nickel slag [37-45]. However, in the process of fire smelting of nickel-iron from laterite, the gangue components in the raw ore are comprehensively treated and applied to high value-added materials, so as to realize the green metallurgical utilization of laterite nickel, which has the characteristics of low cost, high added value, and short flowing time. There are great similarities between technology and equipment in traditional rotary kiln production of direct reducing iron and cement clinker production. First of all, the main equipment is the same rotary kiln, and the raw materials for the production of cement clinker are similar to the gangue composition in iron ore. Secondly, their main production processes are the same. All raw materials must be processed by the process of abrasive mixing-roasting-abrasive, and the roasting temperature is relatively close. The difference is that in the production process of direct reduced iron, it is necessary to separate the direct reduced iron from the gangue components after grinding by means of magnetic separation, while the purpose of cement clinker abrasive is to control the size of cementing materials. In the traditional direct reduced iron production process, gangue formation consumes a lot of energy in each process, but it cannot form high value-added products in the end. Instead, it is treated as solid waste.

Due to the correlation between the two production processes, we proposed the idea of coupling the process of preparing direct reduced iron with the process of preparing cementitious materials. The purpose of the experiment is to design a reaction coupling process. In the process of preparing direct reduced iron or nickel-iron alloy, it can also make the gangue component in the ore react with the $\mathrm{CaO}$ flux to produce the cementitious material. In a material flow and energy flow process, two different valuable products of nickel-iron alloy and cementitious material can be obtained without producing solid waste. Compared with the traditional process, the new process has the characteristics of high energy efficiency, high resource efficiency, and no solid waste. In this study, while preparing nickel iron from carbon base of laterite nickel ore by direct reduction, the gelling materials with silicate tricalcium silicate $\left(\mathrm{C}_{3} \mathrm{~S}\right)$ and aluminate tricalcium $\left(\mathrm{C}_{3} \mathrm{~A}\right)$ as main components were prepared from coal gangue. The coupling of these two reaction processes was investigated experimentally.

\section{Material Analysis and Burdening}

In the experiment, X-ray diffraction (XRD) analysis and fluorescence spectroscopy chemical component analysis were performed on the raw laterite nickel ore (Jinchuan Group Ltd., 
South Halmahera, Indonesia). The X-ray diffractometer used for detection is the Empyrean type with the scanning rate of $8^{\circ} / \mathrm{min}$ from PANalytical B.V (Almelo, Netherlands). The XRD analysis result from the laterite nickel ore is shown in Figure 1, and the chemical components determined through fluorescence spectroscopy are listed in Table 1.

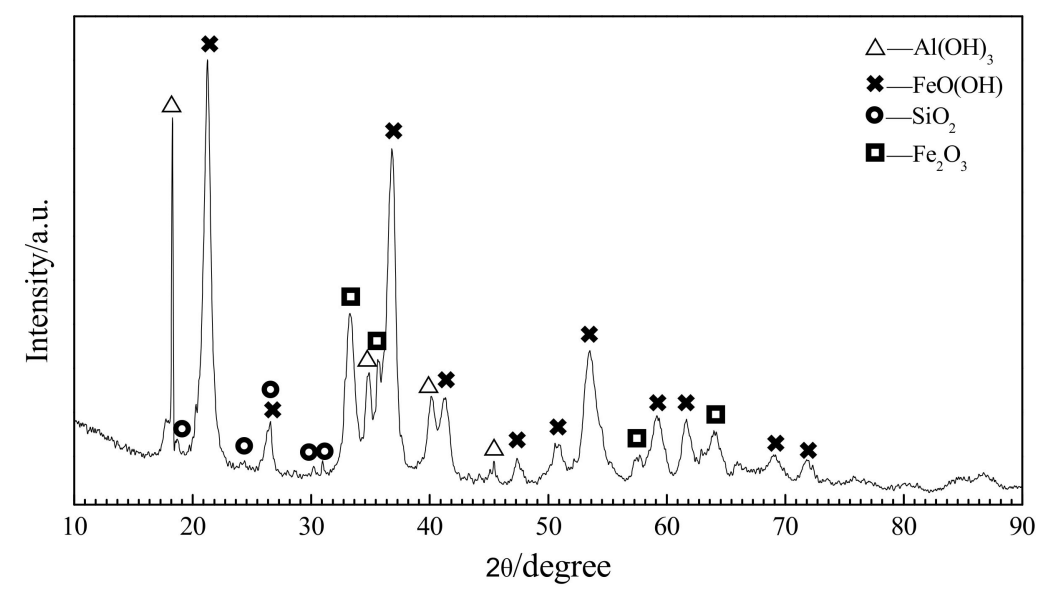

Figure 1. Laterite nickel ore XRD analysis.

Table 1. Chemical components of laterite nickel ore (\%wt.).

\begin{tabular}{lcccccccc}
\hline Components & $\mathrm{NiO}$ & $\mathrm{Fe}_{2} \mathrm{O}_{3}$ & $\mathrm{FeO}$ & $\mathrm{SiO}_{2}$ & $\mathrm{Al}_{2} \mathrm{O}_{3}$ & $\mathrm{CaO}$ & $\mathrm{MgO}$ & Water \\
\hline Content & 1.54 & 65.23 & 0.44 & 3.30 & 8.77 & 0.96 & 1.51 & 17.31 \\
\hline
\end{tabular}

The figure shows that the main phases of the laterite nickel ore are $\mathrm{FeO}(\mathrm{OH})$ (Goethite), $\mathrm{Al}(\mathrm{OH})_{3}(\mathrm{Gibbsite})$, and $\mathrm{Fe}_{2} \mathrm{O}_{3}$. The XRD peaks for the $\mathrm{SiO}_{2}$ phase are comparatively lower, and those for other minerals with calcium, magnesium, and nickel are not obvious. The laterite nickel ore thus has $\mathrm{FeO}(\mathrm{OH}), \mathrm{Al}(\mathrm{OH})_{3}$, and $\mathrm{Fe}_{2} \mathrm{O}_{3}$ as the main components.

According to XRD analysis and fluorescence spectroscopy, in the laterite nickel ore, $\mathrm{FeO}(\mathrm{OH})$ and $\mathrm{Fe}_{2} \mathrm{O}_{3}$ are the main phases. Among them, the content of $\mathrm{Fe}_{2} \mathrm{O}_{3}$ reaches $46.26 \%$, the content of $\mathrm{SiO}_{2}$ is $3.30 \%$, and the content of $\mathrm{Al}(\mathrm{OH})_{3}$ is equivalent to $\mathrm{Al}_{2} \mathrm{O}_{3}$, which accounts for $8.77 \%$ of the total mass, while the content of $\mathrm{Ca}, \mathrm{Mg}, \mathrm{Ni}$, and other elements is less. Based on these characteristics of phase composition, through thermodynamic analysis and calculation, the process coupling for the reduction of nickel and iron and the formation of $\mathrm{C}_{3} \mathrm{~S}, \mathrm{C}_{3} \mathrm{~A}$, and other cementitious materials via the reaction of $\mathrm{CaO}$ with $\mathrm{SiO}_{2}$ or $\mathrm{Al}_{2} \mathrm{O}_{3}$ is calculated. Other elements with lower contents are not considered in the thermodynamic analysis.

Based on the above analysis, the mix ratio of reactants in the raw material is calculated first. The principle for burdening mainly includes two aspects: (1) The addition of reducing agent must ensure the complete reduction of nickel and iron; (2) the added amount of $\mathrm{CaO}$ must be sufficient to fully react with $\mathrm{SiO}_{2}$ and $\mathrm{Al}_{2} \mathrm{O}_{3}$ to produce $\mathrm{C}_{3} \mathrm{~S}$ and $\mathrm{C}_{3} \mathrm{~A}$. According to these calculations, the ratio of laterite nickel ore and raw materials for reduction roasting is shown in Table 2. All the raw materials are ground to particles of less than 200 mesh in size. Burdening was prepared in conformity with the calculated ratio and reaction samples were made by fully blending. The thermodynamic analysis and calculation were performed based on this sample's ratio of raw materials.

Table 2. Laterite nickel ore reduction roasting burden sheet (\%wt.).

\begin{tabular}{cccc}
\hline Composition & Laterite Nickel Ore & $\mathrm{CaO}$ & $\mathrm{C}$ \\
\hline Ratio & 68.42 & 19.03 & 12.55 \\
\hline
\end{tabular}




\section{Thermodynamic Analysis of Coupling Reaction}

In the reduction roasting process, chemical reactions including the decomposition of $\mathrm{FeO}(\mathrm{OH})$ (Goethite) and $\mathrm{Al}(\mathrm{OH})_{3}$ (Gibbsite), reduction of nickel and iron, reaction of iron oxides with $\mathrm{CaO}$ to form calcium ferrite, reaction of $\mathrm{CaO}$ with $\mathrm{Al}_{2} \mathrm{O}_{3}$ to form $\mathrm{CaAl}_{2} \mathrm{O}_{4}(\mathrm{CA})$ and $\mathrm{Ca}_{3} \mathrm{Al}_{2} \mathrm{O}_{6}\left(\mathrm{C}_{3} \mathrm{~A}\right)$, reaction of $\mathrm{CaO}$ with $\mathrm{SiO}_{2}$ to create $\mathrm{Ca}_{3} \mathrm{SiO}_{5}\left(\mathrm{C}_{3} \mathrm{~S}\right.$, alite $)$ and $\mathrm{Ca}_{2} \mathrm{SiO}_{4}\left(\mathrm{C}_{2} \mathrm{~S}\right.$, Belite), and reaction of $\mathrm{CaO}$ with $\mathrm{C}_{2} \mathrm{~S}$ to create $\mathrm{C}_{3} \mathrm{~S}$ may occur. $\mathrm{FeO}(\mathrm{OH})$ and $\mathrm{Al}(\mathrm{OH})_{3}$ can decompose into $\mathrm{Fe}_{2} \mathrm{O}_{3}$ and $\mathrm{Al}_{2} \mathrm{O}_{3}$ after heating, respectively; thus, $\mathrm{Fe}_{2} \mathrm{O}_{3}$ and $\mathrm{Al}_{2} \mathrm{O}_{3}$ are used to replace the original phases in thermodynamic analysis and calculation, following the relevant chemical reaction Equations (1)-(9). Using the Reaction model in FactSage software (FactSage 6.3, Thermfact/CRCT, Montreal, Canada and GTT-Technologies, Aachen, Germany), the possible standard Gibbs free energy produced by the reactions among the main phases during reduction roasting is calculated at intervals of $10{ }^{\circ} \mathrm{C}$ between $0{ }^{\circ} \mathrm{C}$ and $2000{ }^{\circ} \mathrm{C}$, and the relationship of temperature and standard Gibbs free energy $\Delta G$ for each equation is drawn via Origin (Origin 2019, OriginLab, Northampton, MA, USA) as shown in Figure 2 [46].

$$
\begin{gathered}
\mathrm{NiO}+\mathrm{C} \rightarrow \mathrm{Ni}+\mathrm{CO} \\
\mathrm{Fe}_{2} \mathrm{O}_{3}+3 \mathrm{C} \rightarrow 2 \mathrm{Fe}+3 \mathrm{CO} \\
\mathrm{Fe}_{2} \mathrm{O}_{3}+2 \mathrm{CaO} \rightarrow \mathrm{Ca}_{2} \mathrm{Fe}_{2} \mathrm{O}_{5} \\
\mathrm{CaO}+\mathrm{Al}_{2} \mathrm{O}_{3} \rightarrow \mathrm{CaAl}_{2} \mathrm{O}_{4} \\
2 \mathrm{CaO}+\mathrm{CaAl}_{2} \mathrm{O}_{4} \rightarrow \mathrm{Ca}_{3} \mathrm{Al}_{2} \mathrm{O}_{6} \\
3 \mathrm{CaO}+\mathrm{Al}_{2} \mathrm{O}_{3} \rightarrow \mathrm{Ca}_{3} \mathrm{Al}_{2} \mathrm{O}_{6} \\
2 \mathrm{CaO}+\mathrm{SiO}_{2} \rightarrow \mathrm{Ca}_{2} \mathrm{SiO}_{4} \\
3 \mathrm{CaO}+\mathrm{SiO}_{2} \rightarrow \mathrm{Ca}_{3} \mathrm{SiO}_{5} \\
\mathrm{CaO}+\mathrm{Ca}_{2} \mathrm{SiO}_{4} \rightarrow \mathrm{Ca}_{3} \mathrm{SiO}_{5}
\end{gathered}
$$

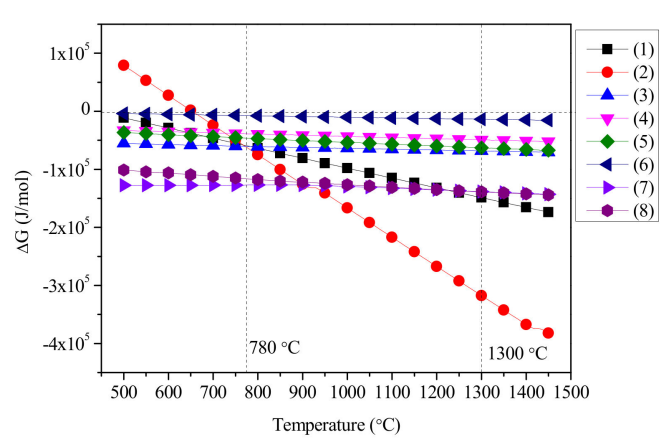

(a)

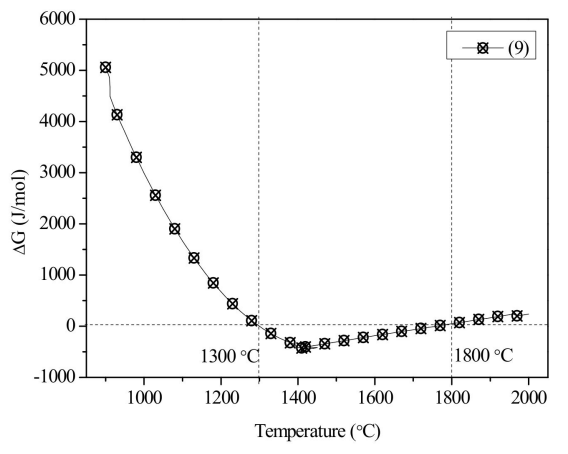

(b)

Figure 2. Laterite nickel ore coupling reaction $\Delta G-T$ : (a) Equations (1)-(8); (b) Equation (9).

As shown in Figure 2a, in the temperature range $500-1450{ }^{\circ} \mathrm{C}$, Equations (1), (3), and (8) proceed spontaneously to realize the reduction of nickel and the production of $\mathrm{CA}, \mathrm{C}_{3} \mathrm{~A}, \mathrm{C}_{2} \mathrm{~S}, \mathrm{C}_{3} \mathrm{~S}$, and $\mathrm{Ca}_{2} \mathrm{Fe}_{2} \mathrm{O}_{5}$. In Equation (2), the temperature at the beginning of iron reduction is $653{ }^{\circ} \mathrm{C}$. At temperatures below $780^{\circ} \mathrm{C}$, the reaction of Equation (3) consumes $\mathrm{CaO}$ and $\mathrm{Fe}_{2} \mathrm{O}_{3}$ and then produces $\mathrm{Ca}_{2} \mathrm{Fe}_{2} \mathrm{O}_{5}$; because the reaction proceeds more easily than iron reduction in Equation (2), this temperature regime is unfavorable for iron reduction. At temperatures above $780{ }^{\circ} \mathrm{C}$, the reaction of Equation (2) proceeds before that of Equation (3); $\mathrm{Fe}_{2} \mathrm{O}_{3}$ is reduced to iron and the temperature for $\mathrm{Fe}_{2} \mathrm{O}_{3}$ reduction should be higher than $780^{\circ} \mathrm{C}$, under which nickel reduction can also occur. 
Through the comparison of the $\Delta \mathrm{G}$-T curves of Equations (4)-(6) in Figure 2a, when the temperature is above $500{ }^{\circ} \mathrm{C}, \mathrm{CaO}$ and $\mathrm{Al}_{2} \mathrm{O}_{3}$ react to produce $\mathrm{C}_{3} \mathrm{~A}$ more easily. The product of $\mathrm{CA}$ also reacts further with $\mathrm{CaO}$ to produce $\mathrm{C}_{3} \mathrm{~A}$; therefore, at high temperatures, the reaction of $\mathrm{CaO}$ with $\mathrm{Al}_{2} \mathrm{O}_{3}$ finally produces the $\mathrm{C}_{3} \mathrm{~A}$ phase.

Through the comparison of the $\Delta \mathrm{G}-\mathrm{T}$ curves of Equations (7) and (8) in Figure 2a, at $1300{ }^{\circ} \mathrm{C}$, the reaction given by Equation (7) proceeds more easily compared to that given by Equation (8) to produce $\mathrm{C}_{2} \mathrm{~S}$. At temperatures above $1300^{\circ} \mathrm{C}, \mathrm{C}_{3} \mathrm{~S}$ is more easily produced. From Figure $2 \mathrm{~b}$, only at temperatures between $1300^{\circ} \mathrm{C}$ and $1800{ }^{\circ} \mathrm{C}$ does the reaction of Equation (9) occur spontaneously; then, $\mathrm{C}_{2} \mathrm{Se}$ produced early in the reaction reacts with calcium oxide to generate $\mathrm{C}_{3} \mathrm{~S}$. Combining Figure $2 \mathrm{a}, \mathrm{b}$, to acquire a cementitious material with $\mathrm{C}_{3} \mathrm{~A}$ and $\mathrm{C}_{3} \mathrm{~S}$ as the main phases, the temperature must be between $1300^{\circ} \mathrm{C}$ and $1800{ }^{\circ} \mathrm{C}$.

To discuss the reactant phase compositions under high temperatures when iron is not fully reduced, the phase model in FactSage software is used to determine the phase diagram for the quaternary oxide system of $\mathrm{CaO}-\mathrm{SiO}_{2}-\mathrm{Al}_{2} \mathrm{O}_{3}-\mathrm{Fe}_{2} \mathrm{O}_{3}$ at $1350{ }^{\circ} \mathrm{C}$. Supposing that unreduced iron comprises $10 \%$ of the total mass of this quaternary oxide system, the resulting phase diagram is as shown in Figure 3.

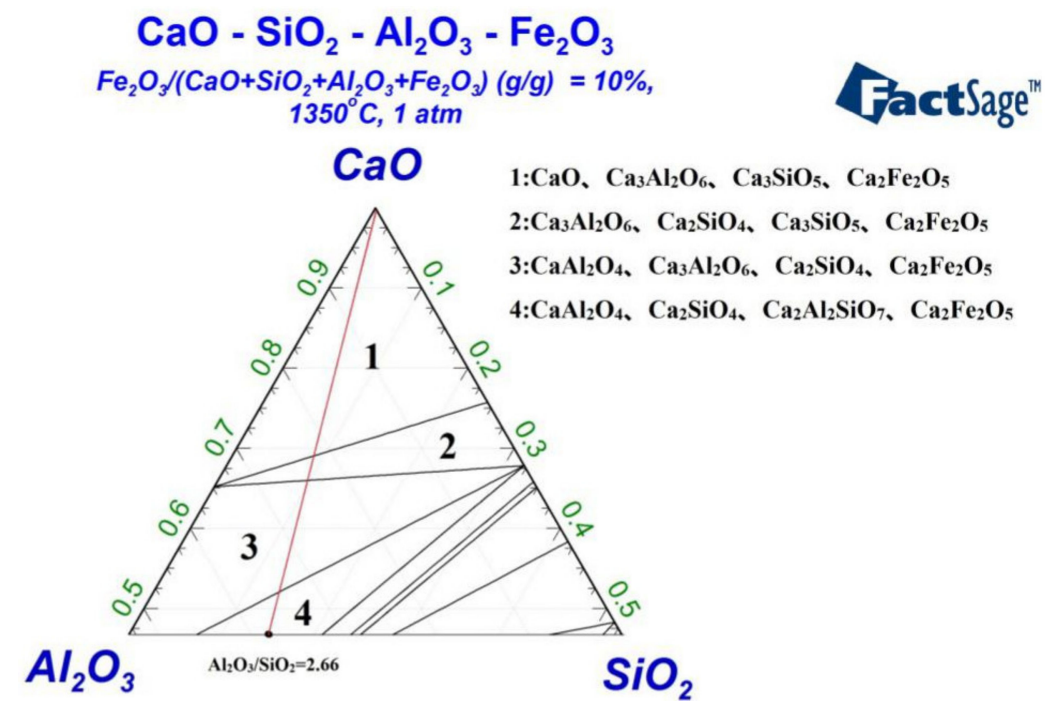

Figure 3. Phase diagram of quaternary oxide system $\mathrm{CaO}-\mathrm{SiO}_{2}-\mathrm{Al}_{2} \mathrm{O}_{3}-\mathrm{Fe}_{2} \mathrm{O}_{3}$ at $1350{ }^{\circ} \mathrm{C}$.

The red line in Figure 3 indicates the raw material ratio of $\mathrm{Al}_{2} \mathrm{O}_{3} / \mathrm{SiO}_{2}=2.66$, equal to that in the laterite nickel ore. The phase composition of the quaternary oxide system varies along the red line as the $\mathrm{CaO}$ content changes. For a continuous increase in $\mathrm{CaO}$ content, the phase composition of the quaternary oxide system also changes correspondingly. For lower $\mathrm{CaO}$ contents (area 4 in the figure), the phase composition includes $\mathrm{CA}, \mathrm{Ca}_{2} \mathrm{SiO}_{4}, \mathrm{Ca}_{2} \mathrm{Al}_{2} \mathrm{SiO}_{7}$, and $\mathrm{Ca}_{2} \mathrm{Fe}_{2} \mathrm{O}_{5}$. As the $\mathrm{CaO}$ content increases (area 3), $\mathrm{CaO}$ reacts with $\mathrm{Ca}_{3} \mathrm{Al}_{2} \mathrm{SiO}_{7}$ to produce $\mathrm{C}_{3} \mathrm{~A}$ and $\mathrm{C}_{2} \mathrm{~S}$, and the $\mathrm{Ca}_{3} \mathrm{Al}_{2} \mathrm{SiO}_{7}$ phase disappears. With further increases in $\mathrm{CaO}$ content (area 2), sufficient $\mathrm{CaO}$ reacts with $\mathrm{CA}$ to form $\mathrm{C}_{3} \mathrm{~A}$ and consume $\mathrm{CA}$; afterward, $\mathrm{CaO}$ reacts with $\mathrm{C}_{2} \mathrm{~S}$ to generate $\mathrm{C}_{3} \mathrm{~S}$. When the $\mathrm{CaO}$ content reaches area $1, \mathrm{C}_{2} \mathrm{~S}$ is fully consumed, for it reacts completely with $\mathrm{CaO}$ to produce $\mathrm{C}_{3} \mathrm{~S}$. Additional $\mathrm{CaO}$ exists in the free state.

In addition, $\mathrm{Fe}_{2} \mathrm{O}_{3}$ reacts with $\mathrm{CaO}$ at $1350{ }^{\circ} \mathrm{C}$ to produce $\mathrm{Ca}_{2} \mathrm{Fe}_{2} \mathrm{O}_{5}$, which coexists with $\mathrm{CA}, \mathrm{C}_{3} \mathrm{~A}$, $\mathrm{C}_{2} \mathrm{~S}$, and $\mathrm{C}_{3} \mathrm{~S}$ (areas 1-4) as impurities in cementitious materials. Thus, $\mathrm{Fe}_{2} \mathrm{O}_{3}$ should be reduced to iron to avoid yielding $\mathrm{Ca}_{2} \mathrm{Fe}_{2} \mathrm{O}_{5}$.

Figure 3 indicates that a sufficiently high $\mathrm{CaO}$ content (areas 1-3) can ensure the coexistence of silicate and aluminate systems independently under high temperatures. To further explore the interaction relationship of reduced iron with the silicate and aluminate systems, FactSage is used to determine the two ternary diagrams of $\mathrm{Fe}-\mathrm{CaO}-\mathrm{Al}_{2} \mathrm{O}_{3}$ and $\mathrm{Fe}-\mathrm{CaO}-\mathrm{SiO}_{2}$. Iron is set to comprise $50 \%$ of the whole, as shown in Figures 4 and 5. 


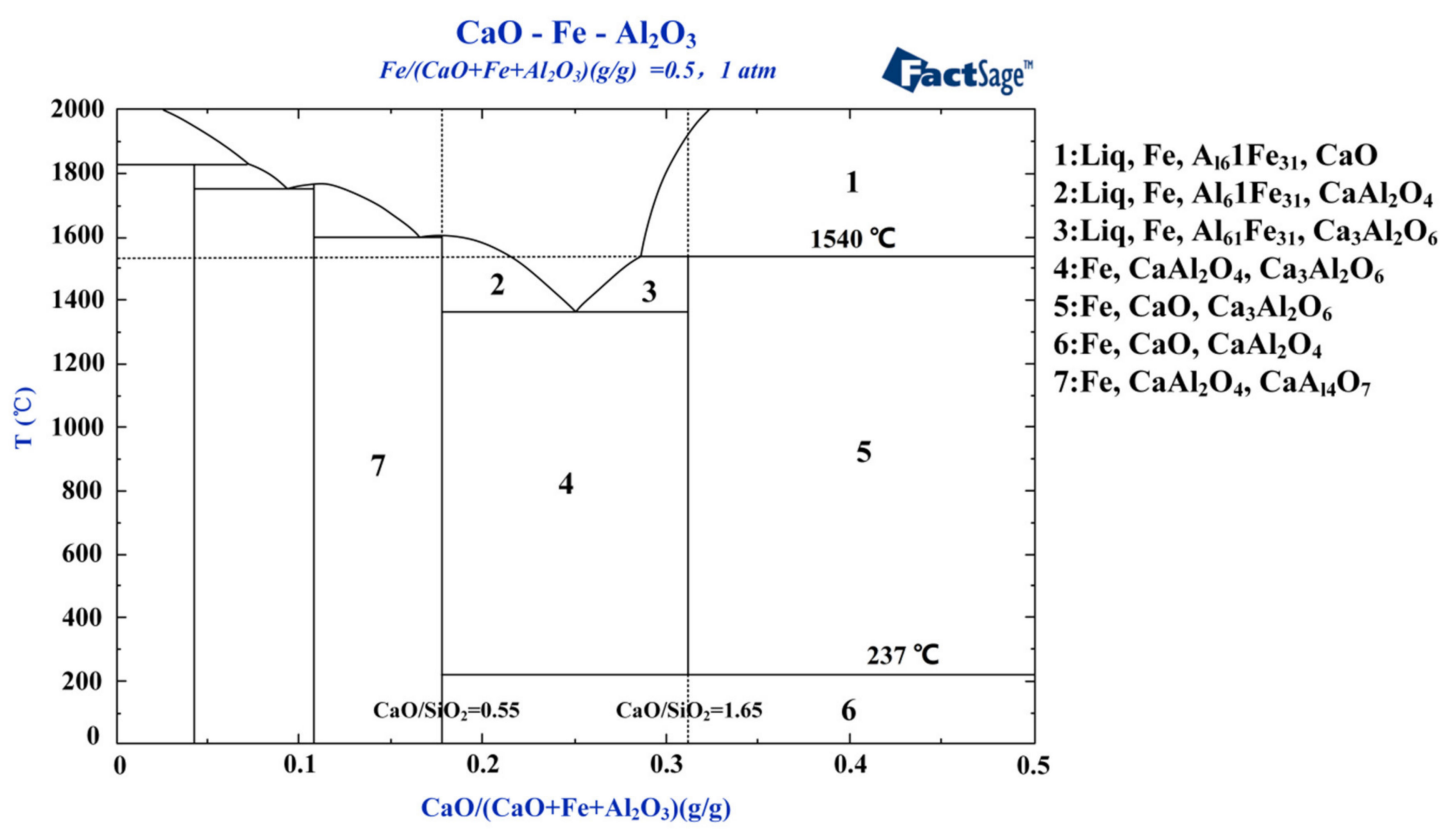

Figure 4. Ternary diagram of $\mathrm{Fe}-\mathrm{CaO}-\mathrm{Al}_{2} \mathrm{O}_{3}$.

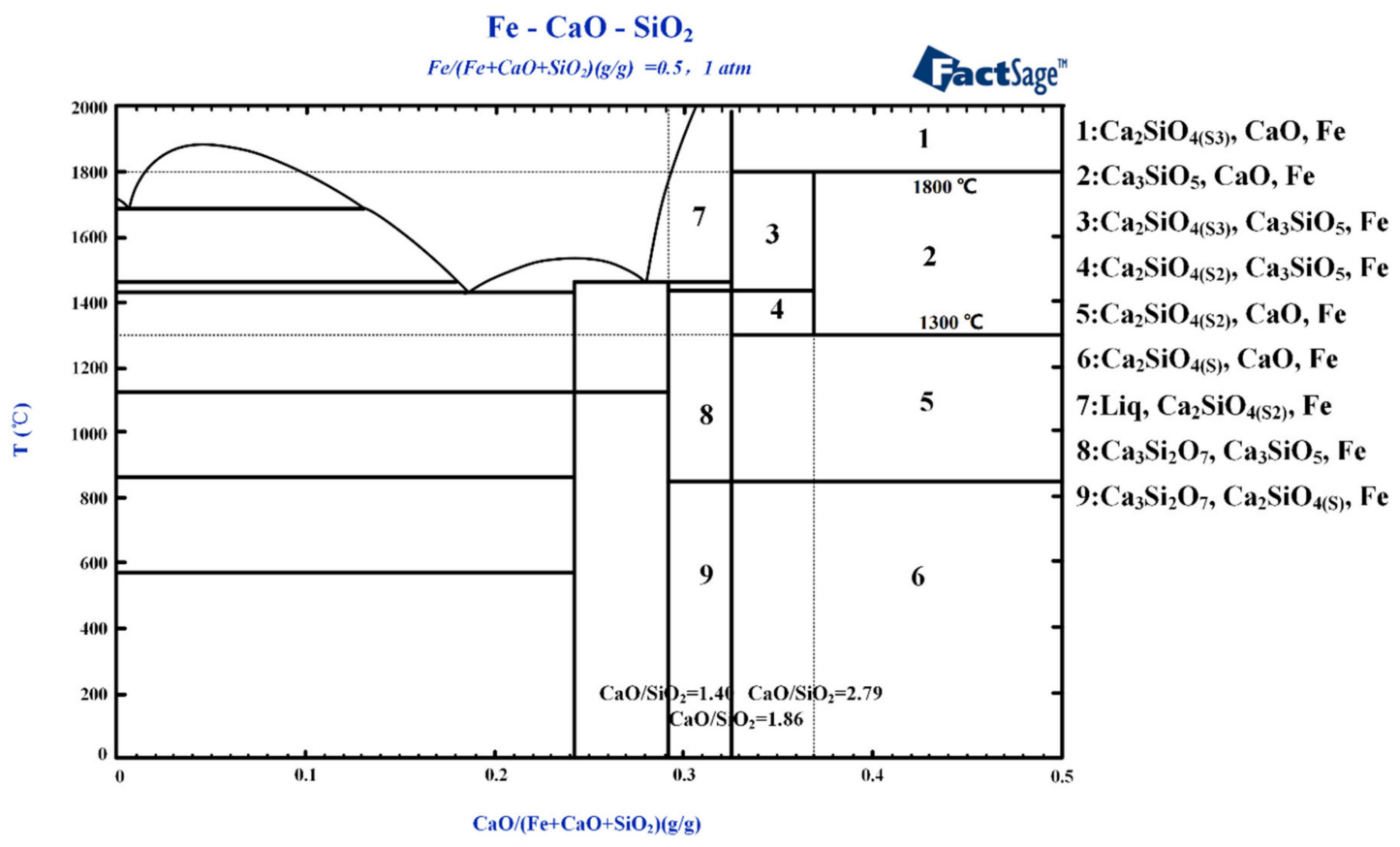

Figure 5. Ternary phase diagram of $\mathrm{Fe}-\mathrm{CaO}-\mathrm{SiO}_{2}$ [46].

Figure 4 demonstrates that $\mathrm{C}_{3} \mathrm{~A}$ is somewhat unstable unless it is produced within the temperature range $237-1540{ }^{\circ} \mathrm{C}$. Stable $\mathrm{C}_{3} \mathrm{~A}$ is produced by the reaction of aluminum oxide with $\mathrm{CaO}$ (areas 3-5). At temperatures below $237^{\circ} \mathrm{C}$ (area 6), $\mathrm{C}_{3} \mathrm{~A}$ is decomposed into $\mathrm{CA}$. At temperatures higher than $1540{ }^{\circ} \mathrm{C}$ (area 1), $\mathrm{C}_{3} \mathrm{~A}$ reacts with the slag liquid phase and decomposes. Reduced iron is not obviously influential on the $\mathrm{CaO}-\mathrm{Al}_{2} \mathrm{O}_{3}$ system, indicating that they can coexist. For temperatures between $237{ }^{\circ} \mathrm{C}$ and $1540{ }^{\circ} \mathrm{C}$ and lower $\mathrm{CaO}$ contents $\left(\mathrm{CaO} / \mathrm{Al}_{2} \mathrm{O}_{3}<0.55\right)$, no $\mathrm{C}_{3} \mathrm{~A}$ forms in the system. The reaction of $\mathrm{CaO}$ with $\mathrm{Al}_{2} \mathrm{O}_{3}$ under these conditions produces $\mathrm{CaAl}_{4} \mathrm{O}_{7}$ and $\mathrm{CaAl}_{2} \mathrm{O}_{4}$, which have lower calcium contents (area 7); as the $\mathrm{CaO}$ content increases to $0.55<\mathrm{CaO} / \mathrm{Al}_{2} \mathrm{O}_{3}<1.65$ (area 7), the low-calcium-content $\mathrm{CaAl}_{4} \mathrm{O}_{7}$ phase disappears and the more calcium-rich $\mathrm{Ca}_{3} \mathrm{Al}_{2} \mathrm{O}_{6}$ phase is produced. $\mathrm{CaAl}_{2} \mathrm{O}_{4}$ ceases forming for $\mathrm{CaO} / \mathrm{Al}_{2} \mathrm{O}_{3}>1.65$, at which point the main phases are $\mathrm{C}_{3} \mathrm{~A}$, free-state $\mathrm{CaO}$, and coexistent iron (area 5), meaning that $\mathrm{CaO} / \mathrm{Al}_{2} \mathrm{O}_{3}=0.55$ and $\mathrm{CaO} / \mathrm{Al}_{2} \mathrm{O}_{3}=1.65$ 
are the composition points of $\mathrm{CaAl}_{2} \mathrm{O}_{4}$ and $\mathrm{Ca}_{3} \mathrm{AlO}_{6}$, respectively. In conclusion, when cementitious materials with the main phase of $\mathrm{C}_{3} \mathrm{~A}$ are prepared, the effective mass of $\mathrm{CaO}$ combined with $\mathrm{Al}_{2} \mathrm{O}_{3}$ should meet the proportion of $\mathrm{CaO} / \mathrm{Al}_{2} \mathrm{O}_{3}=1.65$ in the blending process, and the roasting temperature should be between $237^{\circ} \mathrm{C}$ and $1540{ }^{\circ} \mathrm{C}$.

Figure 5 indicates that $C_{3} S$ is also unstable outside of the temperature range $1300{ }^{\circ} \mathrm{C}$ to $1800{ }^{\circ} \mathrm{C}$. Stable $C_{3} S$ is produced by the reaction of aluminum oxide with $C_{2} S$ (areas 2-4) within this range. When the reaction temperature is lower than $1300{ }^{\circ} \mathrm{C}$ or higher than $1800{ }^{\circ} \mathrm{C}$ (areas 1 and 5 ), $\mathrm{C}_{3} \mathrm{~S}$ is decomposed to $\mathrm{C}_{2} \mathrm{~S}$ and free-state $\mathrm{CaO}$, consistent with the thermodynamic calculations shown in Figure $2 \mathrm{~b}$. Meanwhile, the effect of reduced iron on the $\mathrm{CaO}-\mathrm{SiO}_{2}$ system is not significant, indicating that these three phases can coexist. At temperatures $1300{ }^{\circ} \mathrm{C}-1800{ }^{\circ} \mathrm{C}$ and lower $\mathrm{CaO}$ contents $\left(\mathrm{CaO} / \mathrm{SiO}_{2}<1.40\right)$, neither $\mathrm{C}_{3} \mathrm{~S}$ nor $\mathrm{C}_{2} \mathrm{~S}$ is found in the system. The reaction of $\mathrm{CaO}$ with $\mathrm{SiO}_{2}$ mainly produces $\mathrm{CaSiO}_{3}$ and $\mathrm{Ca}_{3} \mathrm{Si}_{2} \mathrm{O}_{7}$. When the ratio of $\mathrm{CaO} / \mathrm{SiO}_{2}$ is between 1.40 and $1.86, \mathrm{C}_{2} \mathrm{~S}$ exists in the system (areas 7 and 8); when the ratio range is 1.86 to $2.79, C_{2} S$ and $C_{3} S$ can coexist in the system (areas 3 and 4); when the ratio range exceeds $2.79, \mathrm{C}_{3} \mathrm{~S}$, free-state $\mathrm{CaO}$, and coexistent $\mathrm{Fe}$ (area 2) are the main phases, meaning that $\mathrm{CaO} / \mathrm{SiO}_{2}=1.40$ and $\mathrm{CaO} / \mathrm{SiO}_{2}=1.86$ are the composition points of $\mathrm{Ca}_{3} \mathrm{Si}_{2} \mathrm{O}_{7}$ and $\mathrm{C}_{2} \mathrm{~S}$, respectively. In conclusion, when the cementitious materials with the main phase of $\mathrm{C}_{3} \mathrm{~S}$ are prepared, the effective mass of $\mathrm{CaO}$ combined with $\mathrm{SiO}_{2}$ should meet the proportion $\mathrm{CaO} / \mathrm{SiO}_{2}=2.79$ in the blending process, and the roasting temperature should be between $1300{ }^{\circ} \mathrm{C}$ and $1800{ }^{\circ} \mathrm{C}$.

With powdered carbon as the reducing agent, laterite nickel ore as the raw material, and $\mathrm{CaO}$ as the additive, the theoretical analysis results of the changes in the phase composition of the reactants during heating are calculated under a protective $\mathrm{CO}$ atmosphere, by the equipment module in the FactSage software. As shown in Table 2, the reactant proportion was the same. Figure 6 shows the calculation result of the theoretical reaction product, which analyzes the phase change of the system from $500{ }^{\circ} \mathrm{C}$ to $1500{ }^{\circ} \mathrm{C}$ in a temperature interval of $50{ }^{\circ} \mathrm{C}$.

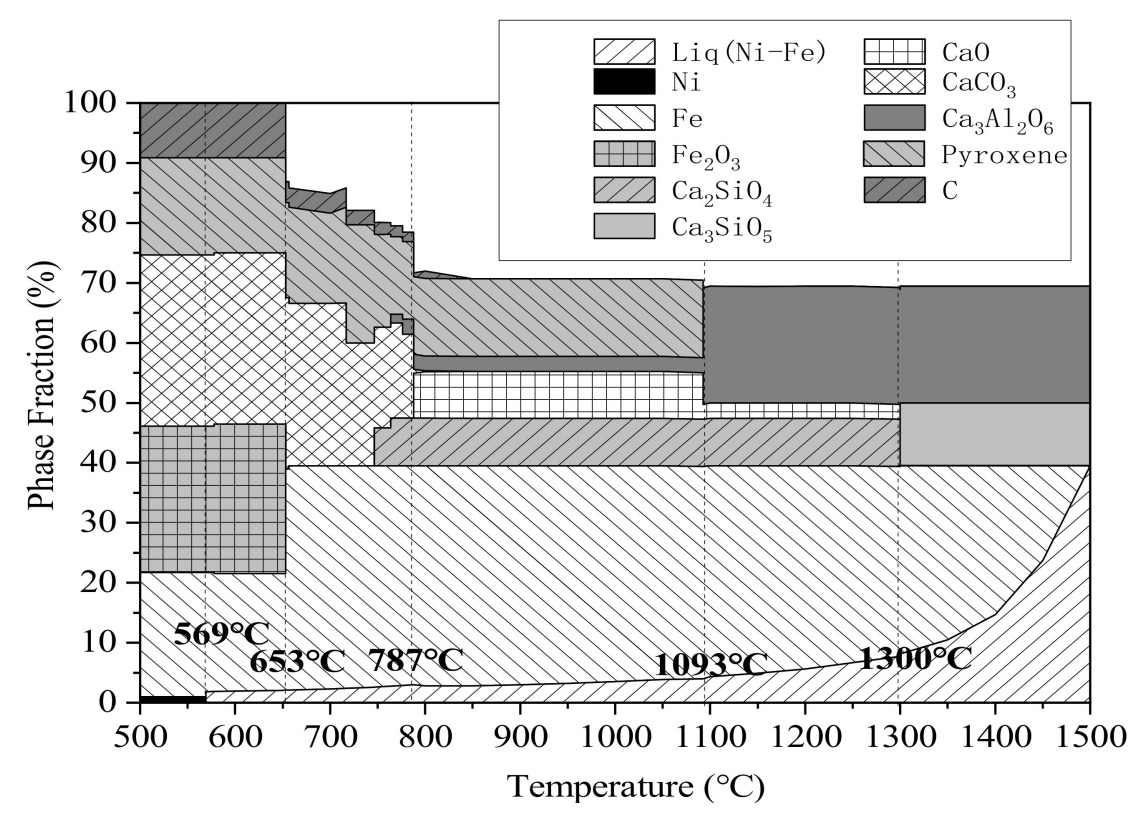

Figure 6. Diagram of variations in laterite nickel ore reduction roasting products.

It can be seen from Figure 6 that in the reaction in the low temperature zone $\left(<569^{\circ} \mathrm{C}\right)$, the phases formed are mainly carbon, pyroxene, $\mathrm{CaCO}_{3}, \mathrm{Fe}_{2} \mathrm{O}_{3}$, nickel, and partly reduced iron. When the temperature exceeds $569^{\circ} \mathrm{C}$, a liquid iron-nickel phase is formed with a high content of nickel; the ratio of this liquid alloy phase increases with increasing of temperature. At temperatures above $653{ }^{\circ} \mathrm{C}$, most of the $\mathrm{Fe}_{2} \mathrm{O}_{3}$ and carbon reactants are consumed to form iron. For temperatures above $787^{\circ} \mathrm{C}$, $\mathrm{CaCO}_{3}$ is decomposed into $\mathrm{CaO}$, part of which reacts with $\mathrm{SiO}_{2}$ and $\mathrm{Al}_{2} \mathrm{O}_{3}$ to generate $\mathrm{C}_{2} \mathrm{~S}$ and some $\mathrm{Ca}_{3} \mathrm{Al}_{2} \mathrm{O}_{6}$, while the pyroxene is consumed. When the reaction temperature is between $1093{ }^{\circ} \mathrm{C}$ and 
$1300{ }^{\circ} \mathrm{C}$, there is no obvious change in each phase, and the main components of liquid iron-nickel alloy, iron, $\mathrm{CaO}, \mathrm{Ca}_{3} \mathrm{Al}_{2} \mathrm{O}_{6}$, and $\mathrm{C}_{2} \mathrm{~S}$. However, at temperatures above $130{ }^{\circ} \mathrm{C}, \mathrm{C}_{3} \mathrm{~S}$ is formed by the reaction of $\mathrm{CaO}$ and $\mathrm{C}_{2} \mathrm{~S}$. Under high-temperature reaction, the final products are liquid iron-nickel alloy, $\mathrm{Ca}_{3} \mathrm{Al}_{2} \mathrm{O}_{6}$, and $\mathrm{C}_{3} \mathrm{~S}$.

According to the above-mentioned thermodynamic analysis, it is feasible to prepare a cementitious material of $\mathrm{C}_{3} \mathrm{~A}$ and $\mathrm{C}_{3} \mathrm{~S}$ by the reduction roasting of laterite nickel ore after the appropriate proportioning. However, in order to ensure the sufficient reduction of nickel and iron as well as the effective production of $\mathrm{C}_{3} \mathrm{~A}$ and $\mathrm{C}_{3} \mathrm{~S}$, the roasting temperature must be controlled by stages.

The reduction temperature of $\mathrm{Fe}_{2} \mathrm{O}_{3}$ should be controlled at $780-1220{ }^{\circ} \mathrm{C}$ since $\mathrm{Fe}_{2} \mathrm{O}_{3}$ reacts with $\mathrm{CaO}$ to form $\mathrm{Ca}_{2} \mathrm{Fe}_{2} \mathrm{O}_{5}$ which affects iron reduction. Thus, in order to ensure complete iron reduction and prevent the formation of low-melting-point liquid fayalite (which melts at $1220{ }^{\circ} \mathrm{C}$ ) by $\mathrm{Fe}_{2} \mathrm{O}_{3}$ and $\mathrm{SiO}_{2}$, this temperature should be maintained for a certain period of time. Under these conditions, $\mathrm{C}_{2} \mathrm{~S}$ and a small amount of $\mathrm{Ca}_{3} \mathrm{Al}_{2} \mathrm{O}_{6}$ can be produced. After the sufficient reduction of iron, the temperature is increased again and then maintained at $1300-1540{ }^{\circ} \mathrm{C}$ (the temperature range for forming stable existent $\mathrm{C}_{3} \mathrm{~S}$ is $1300-1800^{\circ} \mathrm{C}$, that for the decomposition of pyroxene is $1093^{\circ} \mathrm{C}$, and that for stable existent $C_{3} A$ is $237-1540{ }^{\circ} \mathrm{C}$ ). In this regime, the formation of $C_{3} S$ and the reaction of pyroxene after decomposition with $\mathrm{CaO}$ to form $\mathrm{Ca}_{3} \mathrm{Al}_{2} \mathrm{O}_{6}$ are accomplished. Finally, the samples are cooled by fast cooling; tricalcium silicate is metastable at normal temperatures with this treatment.

\section{Experiments and Results}

To verify the accuracy of the above thermodynamic analyses and calculations, coupled experimental studies are conducted under different reaction conditions. Three different control processes are set using three $8 \mathrm{~g}$ samples placed in separate $\mathrm{Al}_{2} \mathrm{O}_{3}$ crucibles. Each crucible is placed in airtight tube-type resistance furnace with the heating rate set to $10^{\circ} \mathrm{C} / \mathrm{min}$. The controlling processes for the three samples are as follows:

1. No atmospheric protection; the temperature is increased from indoor ambient temperature to $1450{ }^{\circ} \mathrm{C}$ and maintained for $1 \mathrm{~h}$ before cooling to indoor temperature to obtain product $\mathrm{A}$.

2. At the flow rate of $60 \mathrm{~mL} / \mathrm{h}$ under the atmospheric protection of $\mathrm{CO}$, the temperature continues to rise from room temperature to $1000{ }^{\circ} \mathrm{C}$, maintained for $2 \mathrm{~h}$, and then increased to $1450{ }^{\circ} \mathrm{C}$ and maintained for $1 \mathrm{~h}$. Product $\mathrm{B}$ was obtained after furnace cooling to room temperature.

3. The period of cooling applied in (2) is changed. The atmosphere conditions and control process of the temperature increase to $1450^{\circ} \mathrm{C}$ are the same as those used for obtaining sample B. After maintaining the temperature of $1450{ }^{\circ} \mathrm{C}$ for $1 \mathrm{~h}$, by using fast cooling, product $\mathrm{C}$ was obtained.

Finally, the obtained reaction samples were examined by XRD and scanning electron microscopy-energy-dispersive X-ray spectroscopy (SEM-EDS). The XRD equipment was the same as that used for raw material analysis; the SEM analysis equipment was type VEGA II XMU (TESCAN Company, Brno, Czechia); the EDS analysis equipment was type 7718 (Oxford Instruments, London, UK). The XRD and SEM-EDS analysis results are shown in Figures 7 and 8, respectively.

Iron oxide comprises more than $45 \%$ of the total sample mass, and the ferronickel alloy is $40 \%$ of the total mass in the theoretical reaction product. Therefore, it can be seen from the XRD pattern that the intensity of the diffraction peaks of iron-nickel alloy and iron oxide is higher than that of other phases.

As can be seen from the XRD analysis results, sample A shows incomplete iron reduction, attributed to the lack of atmosphere protection; iron is present as unreacted $\mathrm{Fe}_{2} \mathrm{O}_{3}$ and $\mathrm{Ca}_{2} \mathrm{Fe}_{2} \mathrm{O}_{5}$ after reacting with $\mathrm{CaO}$. The consumption of $\mathrm{CaO}$ causes the reduction of $\mathrm{CaO} / \mathrm{Al}_{2} \mathrm{O}_{3}$ and $\mathrm{CaO} / \mathrm{SiO}_{2}$. The diffraction peaks of the low calcium phase appear obviously in the XRD pattern of the reaction products, such as $\mathrm{CaAl}_{2} \mathrm{O}_{4}$ and $\mathrm{Ca}_{2} \mathrm{SiO}_{4}$. At the same time, the diffraction peaks of $\mathrm{Ca}_{3} \mathrm{Al}_{2} \mathrm{O}_{6}$ have a weak diffraction peak, which is consistent with the analysis results in Figure 3 . At $1000{ }^{\circ} \mathrm{C}$ for $2 \mathrm{~h}$, 
sample B reacts in a reducing atmosphere to ensure that the nickel-iron is completely reduced to form an iron-nickel alloy, and is then held at $1450{ }^{\circ} \mathrm{C}$ for $1 \mathrm{~h}$ to form $\mathrm{C}_{3} \mathrm{~S}$. However, as a result of furnace cooling, $\mathrm{C}_{3} \mathrm{~S}$ is decomposed into $\mathrm{C}_{2} \mathrm{~S}$ and $\mathrm{CaO}$ phases. Therefore, the final products of sample $\mathrm{B}$ are iron, $\mathrm{CaO}, \mathrm{Ca}_{2} \mathrm{SiO}_{4}, \mathrm{CaAl}_{2} \mathrm{O}_{4}$, and $\mathrm{Ca}_{3} \mathrm{Al}_{2} \mathrm{O}_{6}$, which are consistent with the analysis results of Figures 4 and 5. Sample $\mathrm{C}$ uses the same heating control method as sample $\mathrm{B}$ under the protection of $\mathrm{CO}$ to achieve the reduction of nickel-iron to form iron-nickel alloys, $\mathrm{C}_{3} S$ and $\mathrm{C}_{3} \mathrm{~A}$. $\mathrm{C}_{3} \mathrm{~S}$ avoids the large-scale decomposition using rapid cooling. The final products are iron, $\mathrm{C}_{3} \mathrm{~S}$, and $\mathrm{Ca}_{3} \mathrm{Al}_{2} \mathrm{O}_{6}$, and the decomposition products are $\mathrm{CaAl}_{2} \mathrm{O}_{4}$ and $\mathrm{Ca}_{2} \mathrm{SiO}_{4}$, which show obviously stronger XRD peaks than that of $\mathrm{Ca}_{2} \mathrm{SiO}_{4}$ in sample B. Simultaneously, the SEM-EDS analysis and scanning of sample C show that the morphology of the product is composed of many iron grains with different grain diameters and the cementing material in them. The distributions of nickel and iron are the same; those of calcium, aluminum, silicon, and oxygen are the same, and clear boundaries are observed between the ferronickel alloy and the cementitious materials. The analytical results of theoretical products shown in Figure 6 are consistent with the above analytical results.

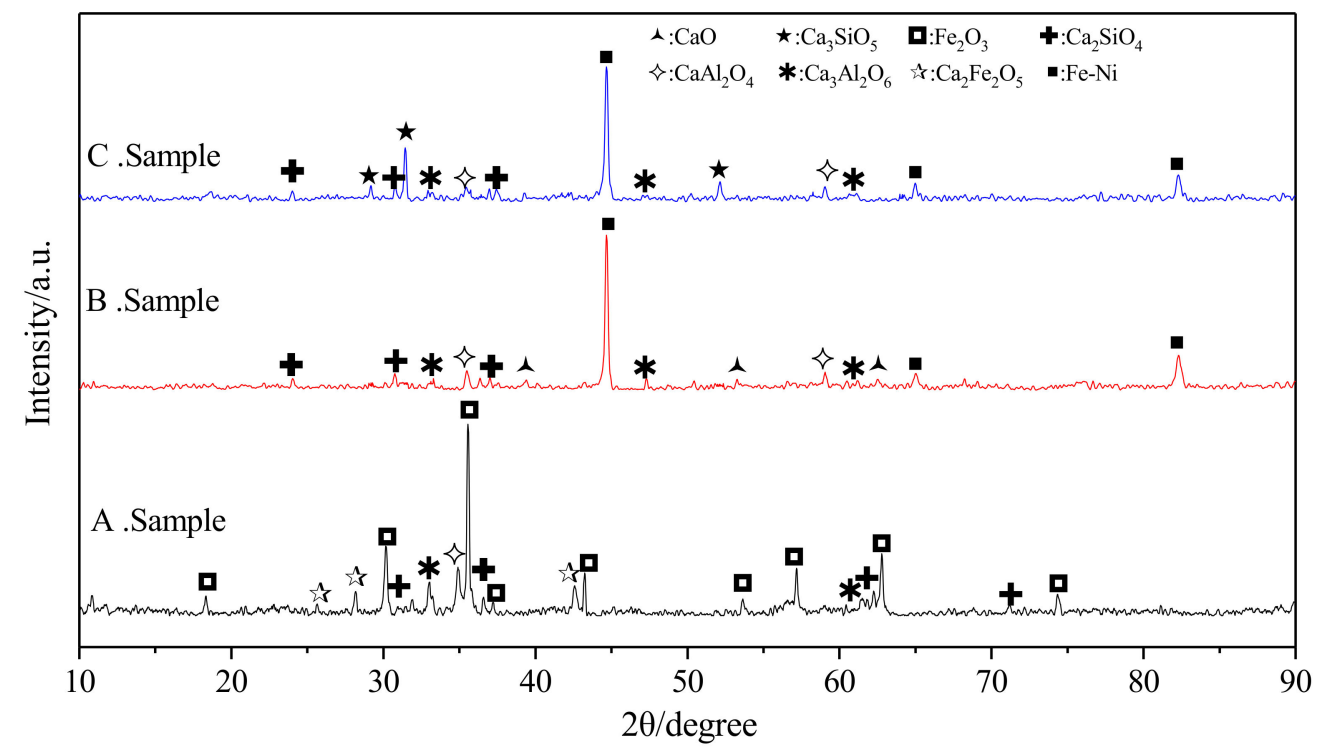

Figure 7. XRD analysis for reduction roasting products of laterite nickel ore.

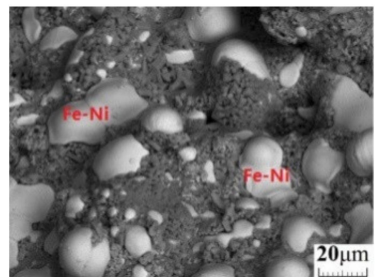

(a)

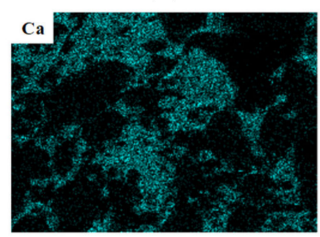

(d)

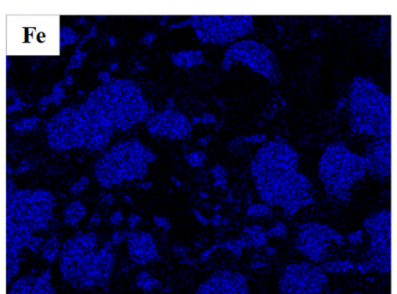

(b)

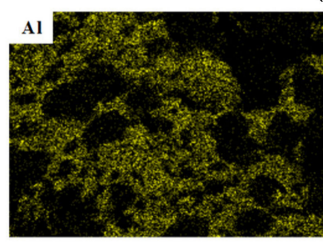

(e)

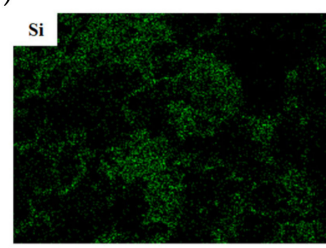

(f)

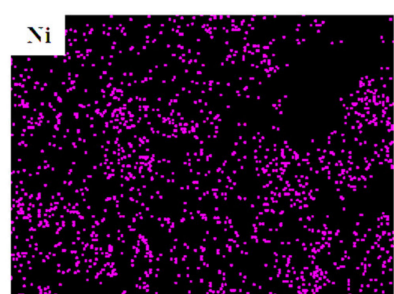

(c)

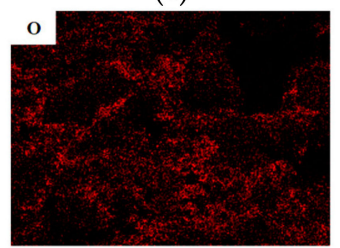

(g)

Figure 8. SEM-EDS analysis chart of sample C: (a) SEM analysis; (b) EDS analysis of Fe; (c) EDS analysis of Ni; (d) EDS analysis of Ca; (e) EDS analysis of Al; (f) EDS analysis of Si; (g) EDS analysis of O. 


\section{Conclusions}

1. For the preparation of high-temperature coexisting cementitious materials such as ferronickel alloy, $C_{3} S, C_{2} S$, etc., it is feasible to reduce and roast laterite nickel ore after proportioning.

2. It is necessary to control the coupling reaction temperature in stages. The reduction temperature of $\mathrm{Fe}_{2} \mathrm{O}_{3}$ is controlled at $780-1220^{\circ} \mathrm{C}$, the formation temperature of $\mathrm{C}_{3} \mathrm{~S}$ is controlled at $1300-1800{ }^{\circ} \mathrm{C}$, and the stability of $\mathrm{C}_{3} \mathrm{~S}$ is controlled at $237-1540{ }^{\circ} \mathrm{C}$. Fast cooling must be applied in order to obtain a metastable $\mathrm{C}_{3} S$ phase.

3. At the reducing atmosphere protection of $\mathrm{CO}$, the first reaction stage is holding at $1000{ }^{\circ} \mathrm{C}$ for $2 \mathrm{~h}$, the second reaction stage is holding at $1450^{\circ} \mathrm{C}$ for $1 \mathrm{~h}$, and fast cooling is used. In this process, ferronickel alloy, $\mathrm{C}_{3} \mathrm{~S}$, and $\mathrm{Ca}_{3} \mathrm{Al}_{2} \mathrm{O}_{6}$ laterite nickel ore are reduced and roasted, and the decomposition products are $\mathrm{Ca}_{2} \mathrm{SiO}_{4}$ and $\mathrm{CaAl}_{2} \mathrm{O}_{4}$ to obtain the final products.

4. The reduction of iron has a significant effect on the formation of $\mathrm{C}_{3} \mathrm{~S}$. When iron is insufficiently reduced, calcium ferrite and other phases are formed in combination with $\mathrm{CaO}$, hindering the formation of $C_{3} S$. The necessary condition for the formation of $C_{3} S$ is the sufficient reduction of iron.

Author Contributions: Methodology, J.Z., X.L., C.Z. and Y.C.; software, J.Z., X.L., C.Z. and Y.C.; validation, J.Z. and X.L.; formal analysis, C.Z. and Y.C.; investigation, J.Z., X.L., C.Z. and Y.C.; data curation, C.Z. and Y.C.; writing-original draft preparation, J.Z.; writing-review and editing, R.S. and G.Q. All authors have read and agreed to the published version of the manuscript.

Funding: The work was financially supported by the National Natural Science Foundation of China (51874224) and Project of young talents in basic research of Natural Science in Shaanxi Province (2014JQ7282).

Conflicts of Interest: The authors declare no conflict of interest.

\section{References}

1. Pollock, T.M.; Tin, S. Nickel-Based Superalloys for Advanced Turbine Engines: Chemistry, Microstructure and Properties. J. Propuls. Power 2006, 22, 361-374. [CrossRef]

2. Hasanbeigi, A.; Arens, M.; Price, L. Alternative emerging ironmaking technologies for energy-efficiency and carbon dioxide emissions reduction: A technical review. Renew. Sustain. Energy Rev. 2014, 33, 645-658. [CrossRef]

3. Moskalyk, R.; Alfantazi, A. Nickel laterite processing and electrowinning practice. Miner. Eng. 2002, 15, 593-605. [CrossRef]

4. Petrus, H.T.B.M.; Rhamdani, A.R.; Putera, A.D.P.; Warmada, I.W.; Yuliansyad, A.T.; Perdana, I. Kinetics study of carbon raiser on the reduction of nickel laterite from Pomalaa, Southeast Sulawesi. In IOP Conference Series: Materials Science and Engineering, Proceedings of the Second International Conference on Chemical Engineering (ICCE) UNPAR, Bandung, Indonesia, 26-27 October 2016; IOP Publishing Ltd: Bristol, UK, 2016; Volume 126, pp. 12-19. [CrossRef]

5. Kostiantyn, T.; Dmitry, B.; Vinod, S.; Gleb, Y. Ten years left to redesign lithium-ion batteries. Nature 2018, 559, 467-470.

6. Brown, T.J.; Wrighton, C.E.; Idoine, N.E.; Raycraft, E.R.; Shaw, R.A.; Deady, E.A.; Rippingale, J.; Bide, T. World Mineral Production 2011-2014; World Mineral Production Series; British Geological Survey: Keyworth, UK, 2017.

7. Crundwell, F.K.; Moats, M.S.; Ramachandran, V.; Robinson, T.G.; Davenport, W.G. Extractive Metallurgy of Nickel, Cobalt and Platinum Group Metals, 1st ed.; Elsevier: Oxford, UK, 2011; pp. 21-37.

8. Farrokhpay, S.; Filippov, L.; Fornasiero, D. Pre-concentration of nickel in laterite ores using physical separation methods. Miner. Eng. 2019, 141, 105892. [CrossRef]

9. Xu, D.; Liu, L.X.; Quast, K.; Addai-Mensah, J.; Robinson, D.J. Effect of nickel laterite agglomerate properties on their leaching performance. Adv. Powder Technol. 2013, 24, 750-756. [CrossRef]

10. Li, X.M.; Bai, T.T.; Zhao, J.X.; Li, W.F.; Li, Z.G.; Cui, Y.R. Status and Progress of Metallurgical Technology on Laterite-Nickel Ore. Mater. Rev. 2014, 28, 112-116.

11. Liu, D.X. Recent Development in Nickel and Cobalt Recovery Technologies from Laterite. Nonferrous Met. 2002, 3, 6-10. 
12. Ma, X.B. Study on Preparing Ferronickel from Laterite by Roasting-Reducing Smelting Method. Master Thesis, Central South University, Hunan, China, 1 May 2010.

13. Ray, H.; Sridhar, R.; Abraham, K. Extraction of Nonferrous Metals; Affiliated East-west Press (pvt.) Ltd.: NewDelhi, India, 1985.

14. Butt, C.R.; Cluzel, D. Nickel laterite ore deposits: Weathered serpentinites. Elements 2013, 9, 123-128. [CrossRef]

15. Pintowantoro, S.; Abdul, F. Selective Reduction of Laterite Nickel Ore. Mater. Trans. 2019, 60, $2245-2254$. [CrossRef]

16. Agatzini-Leonardou, S.; Tsakiridis, P.E.; Oustadakis, P.; Karidakis, T.; Katsiapi, A. Hydrometal lurgical process for the separation and recovery of nickel from sulphate heap leach liquor of nickeliferrous laterite ores. Miner. Eng. 2009, 22, 1181-1192. [CrossRef]

17. Xu, M.; Xu, Q.; Liu, R.Q. Exploitation of Laterite-Nickel Mineral Resources and Technology Advances. Multipurp. Util. Miner. Resour. 2009, 3, 28-30.

18. Chen, J.B.; Xu, J.H. Status quo of nickel mineral resources of our country and countermeasures. Express Inf. Min. Ind. 2006, 25, 1-3, 37.

19. Janwong, A. The Agglomeration of Nickel Laterite Ore. Ph.D. Thesis, University of Utah, Salt Lake City, UT, USA, December 2012.

20. Andika, R.; Astuti, W.; Syafriadi; Nurjaman, F. Effect of flux addition and reductant type in smelting process of Indonesian limonite ore in electric arc furnace. In IOP Conference Series: Materials Science and Engineering, Proceedings of the The 2nd Mineral Processing and Technology International Conference, Tangerang, Banten Province, Indonesia, 1 November 2018; IOP Publishing Ltd: Bristol, UK, 2018; Volume 478.

21. Farrokhpay, S.; Cathelineau, M.; Blancher, S.B.; Laugier, O.; Filippov, L. Characterization of Weda Bay nickel laterite ore from Indonesia. J. Geochem. Explor. 2019, 196, 270-281. [CrossRef]

22. Farrokhpay, S.; Fornasiero, D.; Filippov, L. Upgrading nickel in laterite ores by flotation. Miner. Eng. 2018, 121, 100-106. [CrossRef]

23. Farrokhpay, S.; Filippov, L. Challenges in processing nickel laterite ores by flotation. Int. J. Miner. Process. 2016, 151, 59-67. [CrossRef]

24. Quast, K.; Connor, J.N.; Skinner, W.; Robinson, D.J.; Addai-Mensah, J. Preconcentration strategies in the processing of nickel laterite ores Part 1: Literature review. Miner. Eng. 2015, 79, 261-268. [CrossRef]

25. Quast, K.; Connor, J.N.; Skinner, W.M.; Robinson, D.J.; Li, J.; Addai-Mensah, J. Preconcentration strategies in the processing of nickel laterite ores part 2: Laboratory experiments. Miner. Eng. 2015, 79, 269-278. [CrossRef]

26. Li, J.; Li, X.; Hu, Q.; Wang, Z.; Zhou, Y.; Zheng, J.; Liu, W.; Li, L. Effect of pre-roasting on leaching of laterite. Hydrometallurgy 2009, 99, 84-88. [CrossRef]

27. Lu, J.; Liu, S.; Shangguan, J.; Du, W.; Pan, F.; Yang, S. The effect of sodium sulphate on the hydrogen reduction process of nickel laterite ore. Miner. Eng. 2013, 49, 154-164. [CrossRef]

28. Chen, S.-L.; Guo, X.; Shi, W.-T.; Li, N. Extraction of valuable metals from low-grade nickeliferous laterite ore by reduction roasting-ammonia leaching method. J. Central South Univ. Technol. 2010, 17, 765-769. [CrossRef]

29. Zhu, Z.; Chen, M.-H.; Abernathy, E.; Icenogle, J.; Zhou, S.; Wang, C.; Zhao, C.; Wang, Y.; Chen, H.; Si, Y.; et al. Analysis of complete genomes of the rubella virus genotypes $1 \mathrm{E}$ and $2 \mathrm{~B}$ which circulated in China, 2000-2013. Sci. Rep. 2016, 6, 39025. [CrossRef]

30. Jiang, M.; Sun, T.; Liu, Z.; Kou, J.; Liu, N.; Zhang, S. Mechanism of sodium sulfate in promoting selective reduction of nickel laterite ore during reduction roasting process. Int. J. Miner. Process. 2013, 123, 32-38. [CrossRef]

31. Ma, B.; Wang, C.; Yang, W.; Yin, F.; Chen, Y. Screening and reduction roasting of limonitic laterite and ammonia-carbonate leaching of nickel-cobalt to produce a high-grade iron concentrate. Miner. Eng. 2013, 106-113. [CrossRef]

32. Oliveira, V.D.A.; Dos Santos, C.G.; Brocchi, E.D.A. Assessing the Influence of $\mathrm{NaCl}$ on the Reduction of a Siliceous Laterite Nickel Ore Under Caron Process Conditions. Met. Mater. Trans. A 2019, 50, 1309-1321. [CrossRef]

33. Landers, M.; Gilkes, R. Dehydroxylation and dissolution of nickeliferous goethite in New Caledonian lateritic Ni ore. Appl. Clay Sci. 2007, 35, 162-172. [CrossRef] 
34. Sarbishei, S.; Khajavi, L.T. Kinetic analysis on nickel laterite ore calcination using model-free and model-fitting methods. Miner. Eng. 2019, 136, 129-139. [CrossRef]

35. Oliveira, V.D.A.; Lana, R.D.J.T.; Coelho, H.C.D.S.; Brigolini, G.J.S.; Dos Santos, C.G. Kinetic Studies of the Reduction of Limonitic Nickel Ore by Hydrogen. Met. Mater. Trans. A 2020, 51, 1418-1431. [CrossRef]

36. Sarbishei, S.; Khajavi, L.T. The effect of sulfur content of rotary kiln fuel on the composition of nickel laterite calcine. Fuel 2020, 280, 118648. [CrossRef]

37. Wang, X.F. Simple analysis on pyrometallurgy (RKEF Method) of laterite-nickel ore. Tech. Inno. App. 2013, 1,89 .

38. Wang, C.Y.; Yin, F.; Chen, Y.Q.; Wang, Z.; Wang, J. Worldwide processing technologies and progress of nickel laterites. In Proceedings of the National Academic Conference of Hydrometallurgy in 2008, Ganzhou, China, 1 April 2008; pp. 1-8.

39. Sun, Y.Y.; He, Y.M.; Wang, Y. An elementary introduction on ferronickel technological process. Nonferrous Met. Des. 2008, 35, 7-13.

40. Zhang, B.S.; Jiang, K.X.; Wang, H.B.; Feng, Y.P. Progress of pyrometallurgical smelting technologies for laterite-nickel ore in China. Nonferrous Met. Eng. Res. 2012, 33, 16-19.

41. He, F. Research on direct reduction roasting and magnetic separation of low-grade laterite nickel ore. Hot Work. Technol. 2012, 41, 16-18, 21.

42. Liu, J.J.; Hu, G.R.; Peng, Z.D. The latest and future development of laterite nickel ore processing technology. Rare Met. Cem. Carbides 2011, 39, 62-66.

43. Zhao, G. Simple analysis on ferronickel production technology and its development prospect. Ind. Sci. Trib. 2011, 10, 96-97.

44. Hu, L.B. Analysis of nickel-iron production (I). Ferro-Alloys 2009, 40, 6-10.

45. Zhu, J.W. Ferronickel smelting process comparison: Blast furnace, electric furnace and rotary kiln. Xinjiang Nonferrous Met. 2011, 34, 53.

46. Shi, R.; Zhao, J.; Li, X.; Zou, C.; Cui, Y.; Qiu, G. Experimental Study on the Preparation of Cementing Materials by Direct Reduction Coupling of a Hematite-Carbon Base. Metals 2020, 10, 1086. [CrossRef]

Publisher's Note: MDPI stays neutral with regard to jurisdictional claims in published maps and institutional affiliations.

(C) 2020 by the authors. Licensee MDPI, Basel, Switzerland. This article is an open access article distributed under the terms and conditions of the Creative Commons Attribution (CC BY) license (http://creativecommons.org/licenses/by/4.0/). 